УДК 611.8:611.018.86

Т. М. Мосендз, Б. М. Мицкан

Прикарпатський наиіональний університет ім. Василя Стефаника

\title{
КОМПОЗИЦІЯ ТА ГІСТО-УЛЬТРАСТРУКТУРНА БУДОВА ПРЯМОГО М'ЯЗА СТЕГНА В НОРМІ
}

\begin{abstract}
Наведено дані гістометричного та електронномікроскопічного дослідження м'язових волокон прямого м'яза стегна та їх нервово-м'язових закінчень у щура в нормі. Охарактеризовано основні типи м'язових волокон, показано їх композицію, яка відображає щільну морфологічно взаємозумовлену структуру нервово-м'язових синапсів та м'язової тканини. Це може визначати характер як реактивних, так і деструктивних процесів у скелетних м'язах за різних видів патології.
\end{abstract}

Т. Н. Мосендз, Б. М. Мыцкан

Прикарпатский национальный университет им. В. Стефаника

\section{КОМПОЗИЦИЯ И ГИСТО-УЛЬТРАСТРУКТУРНОЕ СТРОЕНИЕ ПРЯМОЙ МЫШЦЫ БЕДРА В НОРМЕ}

\begin{abstract}
Представлены данные гистометрического и электронномикроскопического исследования мышечных волокон прямой мышцы бедра и их нервно-мышечных окончаний крысы в норме. Дана характеристика основных типов мышечных волокон, показана их композиция, отражающая тесную морфологическую взаимно обусловленную структуру нервно-мышечных синапсов и мышечной ткани. Это может определять характер как реактивных, так и деструктивных процессов в скелетных мышцах при различных видах патологии.
\end{abstract}

\section{T. N. Mosendz, B. M. Mytskan \\ V. Stefanik Precarpatian National University \\ NORMAL COMPOSITION AND HISTO-ULTRASTRUCTURE OF THE RECTUS FEMORIS MUSCLE}

The information on histometric and electron microscopic study of the muscle fibers of the rats' rectus femoris in the norm is presented. The basic types of muscle fibers and their composition are described. The composition reflects the close morphological interdependence of the structure of myoneural junctions and elements of muscular tissue. It may determine different patterns of both reactive and destructive processes in the skeletal muscles.

\section{Вступ}

Скелетні м'язи, як й інші органи, характеризуються різними видами міжтканинних співвідношень [3; 7; 13]. Саме вони визначають морфофункціональну властивість м'яза як органа [8]. Така єдність досягається не тільки завдяки сполучнотканинному каркасу та системі внутрішньом'язової мікроциркуляції крові, а і завдяки периферійному іннерваційному апарату $[2 ; 6]$. Кількість м'язових волокон (MB) і нервовом'язових закінчень (НМ3) у скелетних м'язах різних тварин неоднакова [3; 6]. Характер і розподіл внутрішньом'язових нервових волокон (НВ), кількість НМЗ, насиченість

(C) Т. М. Мосендз, Б. М. Мицкан, 2012 
окремих груп MB ферментами, які визначають їх метаболізм, в окремих м'язах коливається в широкому діапазоні $[12 ; 14 ; 15]$. Ці відмінності відображаються також і на ультраструктурній організації різних груп МВ. Дані наукової літератури щодо міжтканинних співвідношень у різних групах скелетних м'язів мають суперечливий характер. За даними 3. Ч.-М. Хашаева [5], густота внутрішньом'язових НВ і НМ3 залежить перш за все від товщини самих МВ. I навпаки, Б. М. Мицкан [3] вважає, що ступінь іннервації та васкуляризації скелетних м'язів визначається типом обмінних процесів і не залежить від величини МВ. Існує ще одна думка, згідно з якою ангіо- та синаптоархітектоніка залежать від топографії пучків м'язових волокон $[2 ; 10 ; 13]$. Незважаючи на широку наукову дискусію, відомості про кореляцію між композицією скелетних м'язів і характером їх периферійного нервового апарату залишаються неповними та фрагментарними $[1 ; 2 ; 4]$.

Тому мета цієї роботи - охарактеризувати гісто-ультраструктурну будову та композицію прямого м’яза стегна щурів у нормі.

\section{Матеріал і методи досліджень}

Об'єкт дослідження - прямий м'яз стегна (ПМС) та його периферійний нервовом'язовий апарат 5 статевозрілих безпородних щурів-самців. Для дослідження скелетних м'язів використано гістологічний (імпрегнація за Більшовським - Гросс), гістохімічний (за Нахласом) та електронномікроскопічний методи. Ізоферментний спектр ЛДГ визначали за допомогою електрофорезу у поліакриламідному гелі. Забір матеріалу проводили згідно з правилами поводження з експериментальними тваринами [11]. Отриманий матеріал опрацьовано методами непараметричної статистики.

\section{Результати та їх обговорення}

Дослідження ПМС гістохімічними методами дозволило виявити три типи МВ: швидкі окисно-гліколітичні (FOG), швидкі гліколітичні (FG) і повільні окисні (SO). Така класифікація відповідає даним наукової літератури та адекватно відображає характер метаболічних процесів у м'язовій тканині [5; 8; 9]. FOG MB складають 70,1 \%, FG та SO MB - відповідно 27,9 і 2,1 \% (табл. 1).

Ізоферментний спектр ЛДГ ПМС представлено головним чином ізоферментами ЛДГ 4 і ЛДГ , які складають відповідно $23,8 \%$ і $51,9 \%(p<0,05)$. Активність цих

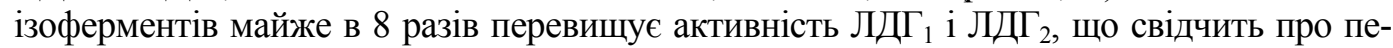
реважання анаеробного шляху метаболізму у ПМС щурів [10;14].

Діаметр і кількість МВ у прямому м'язі стегна білих щурів у нормі $\left(x \pm S_{x}, n=5\right)$

\begin{tabular}{|l|c|c|}
\hline \multicolumn{1}{|c|}{ Тип MB } & Кількість MB & Діаметр MB \\
\hline FOG & $2829 \pm 200^{*}$ & $60,1 \pm 1,8^{*}$ \\
\hline FG & $1125 \pm 115$ & $42,8 \pm 0,9$ \\
\hline SO & $84 \pm 12$ & $35,6 \pm 1,3$ \\
\hline \multicolumn{2}{|c|}{$4038 \pm 312$} \\
\hline
\end{tabular}

Примітка: ${ }^{*} p<0,05$.

Електронномікроскопічні ознаки MB SO-типу - значна кількість ліпідних включень і велика кількість глікогену в усіх відділах MB, а також велика об'ємна щільність мітохондрій різного розміру (рис. $1 a$ ), які займають у середньому $15,68 \pm 1,18$ \% об'єму MB. Міофібрили мають добре виражені смуги $\mathrm{H}$ із М-лініями та Z-пластинки розміром 100-110 нм. Саркоплазматичний ретикулум (СР) має доволі густу сітку канальців і 
порівняно невеликі термінальні цистерни. Ядра, які локалізуються субсарколемально, мають добре диференційовані ядерця.

FOG MB характеризуються меншою кількістю (відносний об'єм складає тільки $5,75 \pm 0,64 \%)$ і розмірами $(0,5-0,6$ мкм) мітохондрій, які локалізуються $з$ двох боків від Z-лінії (рис. 1б). У них дуже рідко зустрічаються ліпідні включення, проте відмічається велика кількість глікогену, особливо у міжфібрилярному просторі на рівні І-дисків, під сарколемою та поблизу міоядер (у середньому 412,0 $\pm 42,6$ гранул на 10 мкм²). Елементи CP в FOG MB значно краще розвинені, ніж у SO MB. На повздовжніх зрізах у міжфібрилярних проміжках на рівні межі А- та І-дисків саркомерів визначаються тріади (див. рис. 1б), в яких чітко розрізняються Т-трубочки та щільно прилеглі до них iз двох боків термінальні цистерни. Важлива відмінність FOG MB - вміст значно товстішіх міофібрил із вузькою Z-лінією (50-55 нм). При цьому часто спостерігаються міоядра цигаркоподібної форми та, нерідко, із двома ядерцями.

Проміжні (FG) MB відрізняються малою кількістю мітохондрій (рис. 18), при відносному об’ємі $4,96 \pm 0,18 \%(p<0,05)$. СР розвинений слабко, його відносний об'єм складає 7,26 $\pm 0,33 \%$. FG MB мають найширшу Z-лінію (150-180 нм).

Внутрішньом'язові нервові провідники збираються у пучки ( $d=90-120$ мкм), які добре видно на імпрегнованих азотнокислим сріблом гістологічних препаратах (рис. $2 a$ ). У кожному з таких пучків нараховується 10-16 нервових волокон (НВ) серед яких 79,2 \% займають аксони діаметром понад 7,0 мкм. Деякі з них розгалужуються на 3-10 термінальних гілочок (рис. 2б). Їх довжина коливається від 20 до 32 мкм, а діаметр складає $1,0-4,0$ мкм. Дуже часто вони закінчуються невеличким плоским розширенням округлої або овальної форми. У ділянці розгалуження на кінцеві гілочки НВ або їх колатералі втрачають мієлінову оболонку та терміналі аксонів покриваються тільки поодинокими нейролемоцитами (рис. 26,2 ). Середня кількість ядер нейролемоцитів складає $5,4 \pm 0,1$. Площа НМЗ коливається в широких межах: від 498,6 до 926,4 мкм² і становить у середньому $712,5 \pm 14,3$ мкм $^{2}$.

Під електронним мікроскопом НМЗ мають форму заглибини міоцита, в якій лежить кінцева гілочка аксона або ії вузлоподібне відгалуження. У цій ділянці аксолема утворює пресинаптичну мембрану, а ії потовщення утворюють активні зони. Постсинаптична мембрана представлена сарколемою, яка має густо розташовані субсинаптичні складки. Синаптична щілина заповнена периаксональною та периміоцитною базальними мембранами, які в межах синаптичної щілини з'єднуються між собою. Аксональний полюс прикривається 1-2 нейролемоцитами, ядро та цитоплазматичні органели яких мають характерну будову. Аксоплазма термінальних закінчень містить велику кількість синаптичних пухирців i мітохондрій, мікрофіламенти та мікротрубочки. Саркоплазма м'язового полюса заповнюється мітохондріями та ядрами МВ.

Нами встановлено, що синаптоархітектоніка зумовлена фенотипом MB, а відомості про кількість НМЗ у ПМС добре узгоджуються з їх гістохімічним профілем. У FOG-м'язових MB патерн розгалуження рухового аксона зумовлений як претермінальним, так i термінальним спраутингом. Завдяки останньому кожна терміналь утворює 2-3 субтермінальні гілочки. Кількість нейролемоцитів, які добре виявляються при імпрегнації нітратом срібла, складає 10,24 $\pm 1,22$. Усі терміналі стають тоншими у міру віддалення від останнього мієлінового сегмента. Витончення терміналей відбувається нерівномірно уздовж їх ходу. Термінальні гілки мають 4 7 варикозних розширень. Ці варикозні розширення чергуються 3 ділянками терміналі, що повністю ізольовані від контакту з МВ відростками кінцевих нейролемоцитів. 

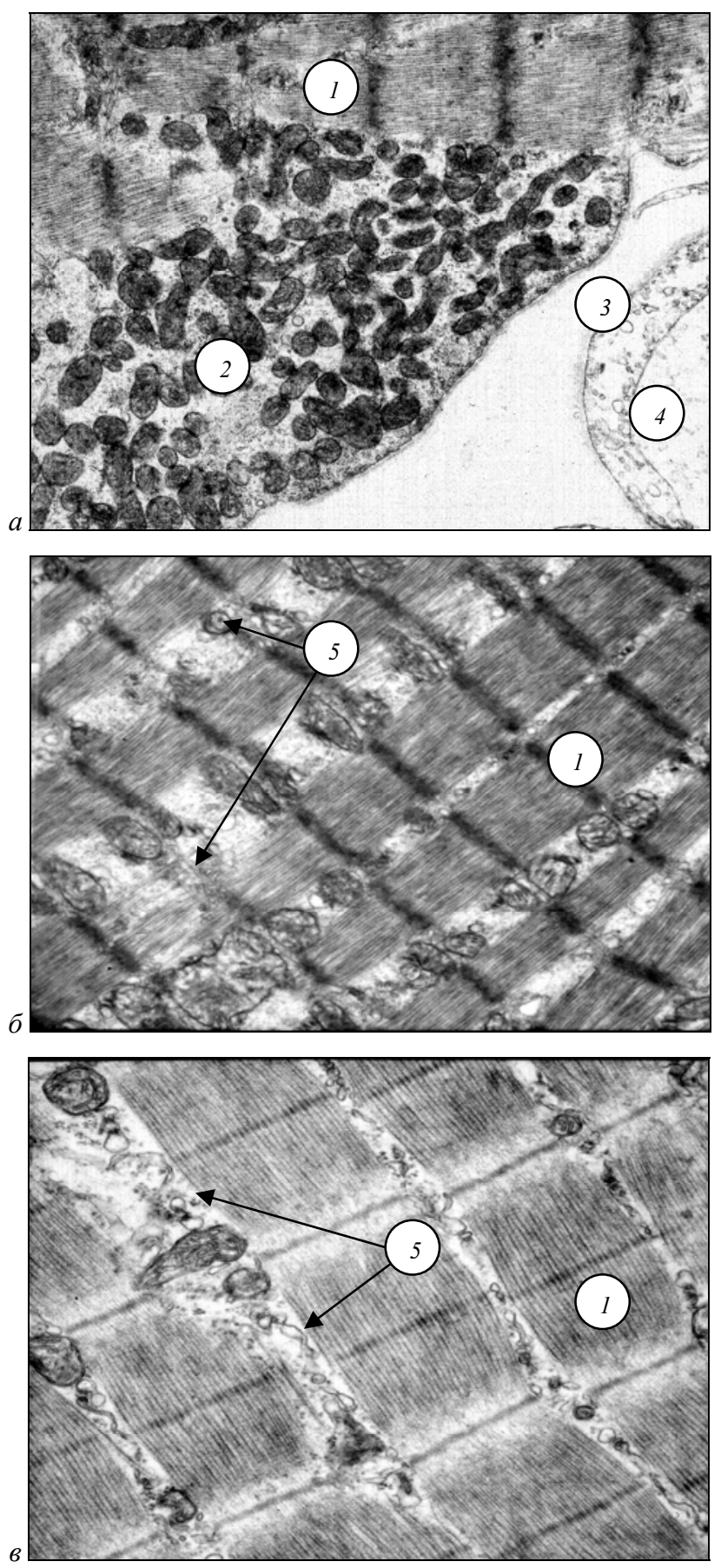

Рис. 1. Ультраструктурна організація SO (a), FOG (б) і FG (в) м'язових волокон прямого м'яза стегна інтактного білого щура: 1 - міофібрили; 2 - мітохондрії; 3 - капілярне ложе; 4 - гемокапіляр; 5 - стрілками показано тріади (б) та канальці саркоплазматичного ретикулуму (в); $a$-х 9 500; $\sigma$-x $10000 ;$ в-x 12000.

У цих місцях терміналь різко зменшена в діаметрі, а аксоплазма містить тільки поодинокі мітохондрії та везикули. Діаметр і довжина варикозних розширень мають 
значні флуктуації уздовж кожної терміналі. Їх величина у центральних ділянках набагато більша, ніж у дистальних. Саме у цих сегментах зосереджено всі структури, характерні для термінальної аксоплазми: активні зони, синаптичні пухирці, мітохондрії, мікротрубочки та нейрофіламенти (рис. 3I).
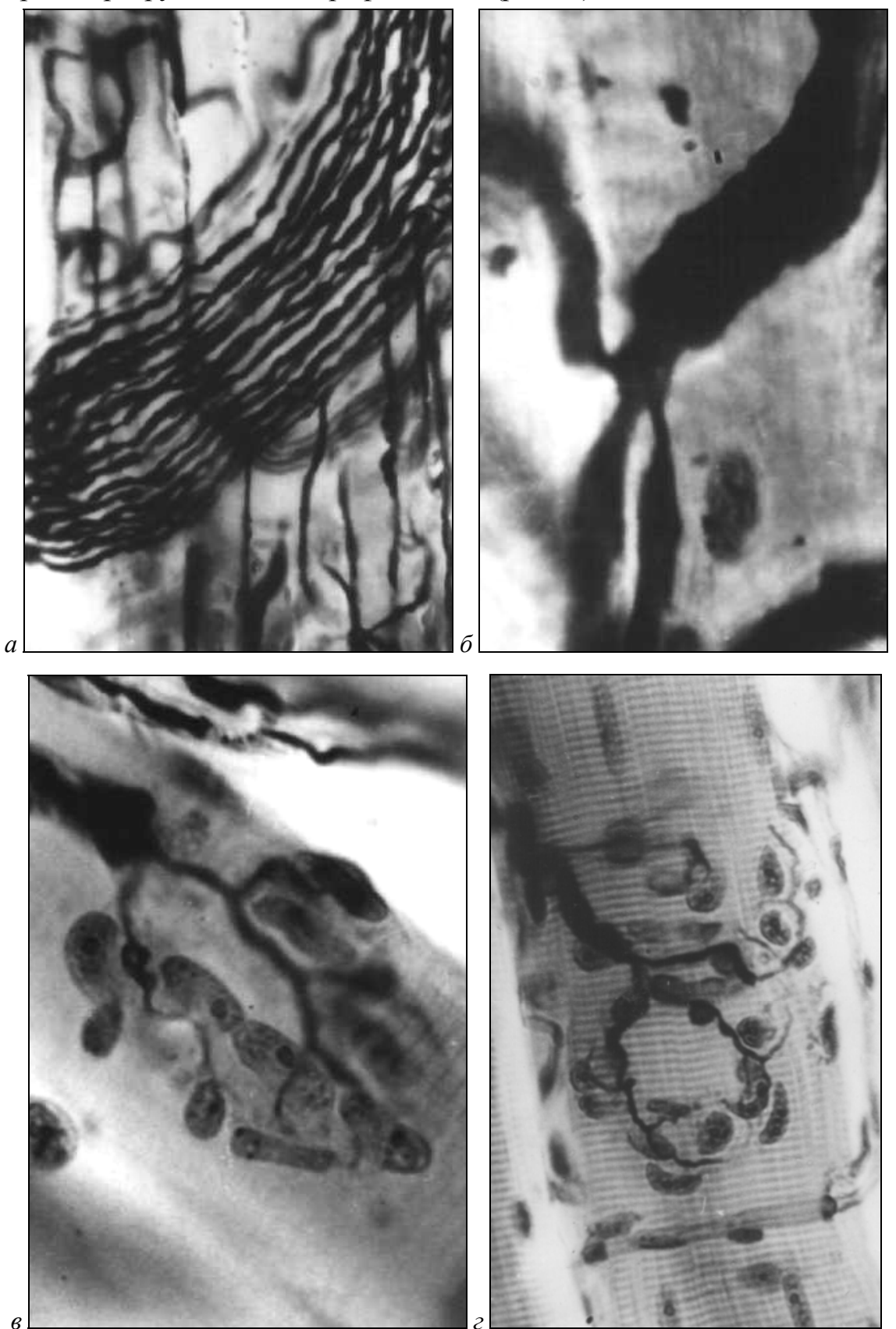

Рис. 2. Міслінові нервові волокна $(a, \sigma)$

та їх кінцеві розгалуження $(6,2)$ у прямому м'язі стегна інтактного щура: імпрегнація за Більшовським - Гросс; $a-x$ 280; $6,6,2-$ х 630 
Кожний сегмент аксонної терміналі включає від 1 до 4 активних зон (АЗ), розміщених напроти постсинаптичних складок. У ділянці АЗ постійно спостерігається скупчення синаптичних пухирців $(10,0 \pm 1,1)$.
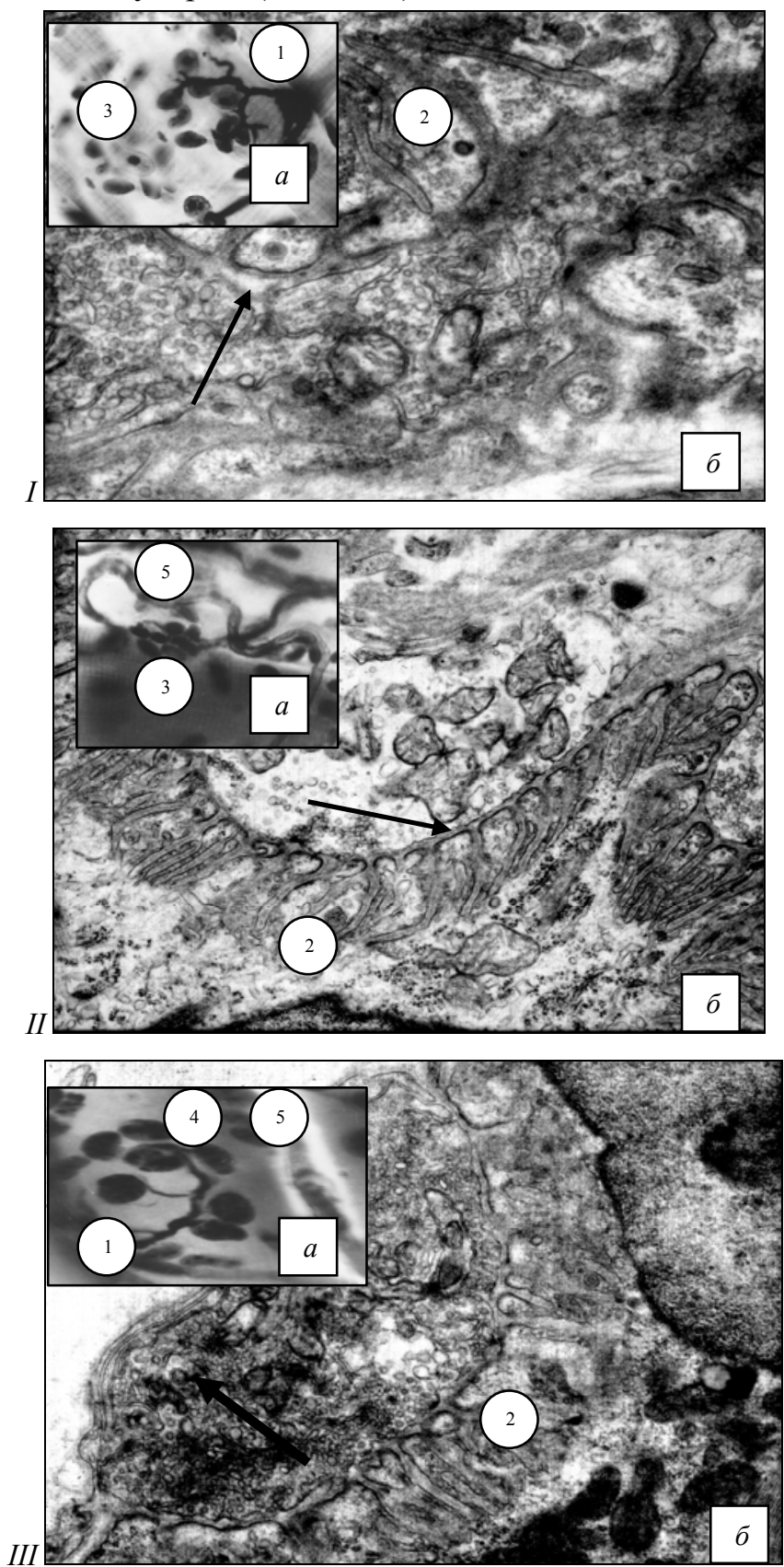

Рис. 3. Нервово-м'язове закінчення (a) та ультраструктурна організація аксом'язового синапсу (б) FOG (I), SO (II) i FG (III) м'язових волокон: 1 - терміналь аксона; 2 - синаптичні складки; 3 - термінальні розгалуження; 4 - ядра кінцевих нейролемоцитів; 5 - гемокапілярна петля; стрілками показано синаптичну щілину; $a$ - імпрегнація за Більшовським - Гросс; $a-\times 800 ; \sigma-\times 15000(I) ; \times 25000(I I) ; \times 10000(I I I)$ 
Синаптична щілина шириною 60-65 нм заповнена колагеноподібною речовиною, так званою базальною мембраною. Постсинаптична мембрана має глибокі, нерідко розгалужені, синаптичні складки, які інколи утворюють між собою анастомози. Відстань між складками становить $0,53 \pm 0,02$ мкм, кількість складок на 1 мкм довжини терміналі дорівнює $1,9 \pm 0,2$. Довжина окремої складки має $1,30 \pm 0,06$ мкм. Просвіт складок заповнений аморфним матеріалом базальної мембрани. Інколи окремі складки продовжуються в типові Т-трубочки, які входять до складу так званих тріад MB. Субсинаптична зона представлена вузьким шаром саркоплазми, яка містить поодинокі мітохондрії, комплекс Гольджі, окремі пухирці, багато гранул глікогену (див. рис. 3I). На ділянці розміщення міоядер підошви субсинаптична зона розширена.

У HM3 SO MB аксон утворює дві короткі термінальні гілки (рис. 3II, a), на ділянці яких розміщується 4-5 нейролемоцитів. Ультраструктурна організація термінальної аксоплазми суттєво не відрізняється від такої в аксом'язових синапсах FOG MB. Поряд із цим синапси SO MB чітко відрізняються ультраструктурною будовою постсинаптичної мембрани. Вона має значно менше складок $(5,2 \pm 1,1)$, які значно коротші та практично не утворюють вторинних розгалужень. Субсинаптична зона розширена та містить велику кількість гранул глікогену та мітохондрій. У цитоплазмі кінцевих нейролемоцитів постійно спостерігаються вторинні лізосоми. Нерідко в мікрорегіоні нервово-м'язового контакту виявляються терміналі безмієлінових МВ (див. рис. $3 I I$, б).

HM3 FG MB за особливостями архітектоніки та ультраструктурної організації наближаються до описаних вище закінчень FOG-міонів. Відмінність полягає в значно ширшій субсинаптичній зоні (рис. 3III).

Відмінності будови НМЗ у різних типах МВ тільки з позицій гетерохронності їх розвитку [4] чи прискореного формування винятково життєво необхідних систем [5; 9] виявити досить важко. Дані нашого дослідження наводять на думку про те, що саме встановлення особливостей обміну, характерного для кожного типу МВ, відображає особливості їх периферичного нервового апарату $[2 ; 8 ; 10]$. Ряд дослідників $[1 ; 3 ; 14 ; 15]$ відводять іннерваційній теорії формування внутрішньом'язових міжтканинних взаємовідносин особливе місце, оскільки метаболічний градієнт кожного МВ залежить від кількості НМЗ, що вказує на морфологічну інтегрованість функціональної системи [2; 3].

\section{Висновки}

Проведене дослідження дає поглиблену уяву про морфофункціональний взаємозв'язок між гісто-ультраструктурною організацією та гістохімічними особливостями м'язових волокон, ї периферичним нервовим аппаратом, відображає відмінності обмінних процесів у прямому м'язі стегна щура в нормі. Виявлені особливості відображають тісну метаболічну взаємодію НМЗ та елементів м'язової тканини в нормі. Неоднаковий ступінь їх вираженості у різних м'язових волокнах може впливати на перебіг патологічних процесів у скелетних м'язах. Перспектива подальших досліджень полягає у вивченні закономірностей гісто-ультраструктурної перебудови нервово-м'язових закінчень при загальній дегідратації організму.

\section{Бібліографічні посилання}

1. Козлова О. В. Динамика изменения лизофосфолипидов при демиелинизации внутримышечных нервов / О. В. Козлова, В. В. Ревин // Фундаментальные исследования. - 2007. - № 1. C. $82-82$. 
2. Михайлов И. В. Возможности исследования состояния периферического нервно-мышечного аппарата человека в клинике и эксперименте / И. В. Михайлов, П. В. Ткаченко // Международный журнал прикладных и фундаментальных исследований. - 2009. - № 5. - С. 25-28.

3. Мицкан Б. М. Вплив обмеження рухової активності на гісто-ультраструктуру скелетних м'язів // Б. М. Мицкан, С. Л. Попель // Прикладні аспекти морфології експериментальних і клінічних досліджень: Матер. наук.-практ. конф. - Тернопіль, 2008. - С. 83-84.

4. Морозов В. И. Изменение мышечных нервов голени белых крыс в постнатальном периоде онтогенеза / В. И. Морозов, В. М. Чучков, О. А. Паксютов // Морфология. - 2002. - Т. 121, № 2. $-\mathrm{C} 108$.

5. Хашаев 3. Х.-М. Изучение механизма передачи информации в нервно-мышечном синапсе // Успехи современного естествознания. - 2006. - № 9. - С. 18-21.

6. Чайковский Ю. Б. Периферический нерв: нейро-сосудисто-десмальные взаимоотношения в норме и при патологии / Ю. Б. Чайковский, С. Б. Геращенко, Е. И. Дельцова // Морфология. 2006. - Т. 129, № 2. - С. 100-102.

7. Швалев В. Н. Нервная ткань и нейроглия. - СПб. : СпецЛит, 2001. - 433 с.

8. Шубникова Е. А. Мышечные ткани. - М. : Медицина, 2001. -240 с.

9. Bayline R. J. Nerve-muscle interactions regulate motor terminal growth and myoblast distribution during muscle development / R. J. Bayline, C. Duch, R. B. Levine // Dev. Biol. - 2001. - Vol. 231. P. 348-363.

10. Candau R. Correlation between cross-bridge kinetics obtained from Trp fluorescence of myofibril suspensions and mechanical studies of single muscle fibers in rabbit psoas / R. Candau, M. Kawai // J. Muscle Res. Cell Motility. - 2011. - Vol. 32, N 4-5. - P. 315-326.

11. European convention for the protection of the vertebrate animals used for experimrntal and other scientific purpose: Counsil of Europe 18.03.1986. - Strasburg, 1986. - 52 p.

12. Franco D. Study of hydrolyzed protein composition, free amino acid, and taurine content in different muscles of galician blonde beef / D. Franco, L. González, E. Bispo // J. Muscle Foods. - 2010. Vol. 21, N 4.- P. 769-784.

13. Nocella M. Non-crossbridge calcium-dependent stiffness in slow and fast skeletal fibres from mouse muscle / M. Nocella, B. Colombini, M. Angela // J. Muscle Res. Cell Motility. - 2011. - Vol. 32, N 4-5. - P. 403-409.

14. Ramanathan R. Effect of lactate enhancement on myoglobin oxygenation of beef longissimus steaks overwrapped in $p v c$ and stored at $4 c$ / R. Ramanathan, R. A. Mancini, M. K. R. Konda // J. Muscle Foods. - 2010. - Vol. 21, N 4. - P. 669-684.

15. Smerdu V. Dynamic nature of fibre-type specific expression of myosin heavy chain transcripts in 14 different human skeletal muscles / V. Smerdu, I. Eržen // J. Muscle Res. Cell Motility. - 2011. Vol. 22, N 8. - P. 647-655.

Надійшла до редколегії 29.03.2012 